\title{
Qualitative University Education and the Problem of Underfunding in Nigeria
}

\author{
Amini-Philps Chinyere (Corresponding author) \\ drchiap22@gmail.com \\ Wordu Goodluck \\ Department of Educational Management \\ Faculty of Education \\ University of Port Harcourt
}

Doi:10.5296/ ijhrs.v5i2.7840 URL: http://dx.doi.org/10.5296/ ijhrs.v5i2.7840

\begin{abstract}
The issue of underfunding of university education in Nigeria is a recurring one and cannot be glossed over. Under funding is viewed as bane of qualitative university education in Nigeria. This paper highlights the trend in establishment and funding of universities nothing that funding of education has remained one of the most challenging problems of universities and the government. It described the concept of quality education, how quality education is perceived in the Nigeria context and various ways in which underfunding has impinged on the quality of university education. It concluded that underfunding has became a recurring have not been sincere in their commitment towards university education. A number of recommendations to ameliorate the situation were made amongst which are: that the government and political class should muster enough political-will and allocate at least $26 \%$ of the total budget to university education as suggested by UNESCO, use of the find allocated to the universities should be closely monitored to forestall misappropriation, allowances paid to political office holders should be received downwards as this would make more money available in government offers and that money accruing from such exercise should be channelled towards providing state-of-the-art laboratories in universities, faith based organizations be made to contribute to universities funding by paying a stipulated percentage of their income to government to augment university funding.
\end{abstract}

Keywords: University education, higher education institutions, underfunding 


\section{Introduction}

The belief that education is an engine of sustainable development rests upon quality education. Education all-over the world is widely accepted as the mechanism for national development and economic growth. No wonder scholars both in Nigeria and elsewhere in the world are unanimous in their agreement of the relevance of university education to overall development of nations. In a similar vein, Ibukun (1997) posited that the main purpose and relevance of university education in Nigeria is the provision of the much needed manpower to accelerate the socio-economic development of the nation.

According to the national policy on education (2004: p 36), the goals of university education among others include:

- Contribute to national development through high level relevant manpower training.

- Develop and inculcate proper values for the survival of the individual and the society.

- Development of intellectual capability of individuals to understand and appreciate their local and external environment.

- Acquire both physical and intellectual skills which will enable individuals to be self-relevant and useful members of the society.

- Promote and encourage scholarship and community services.

- Forge and cement national unity and

- Promote national and international understanding and interactions.

These objectives cannot be achieved if university education is not adequately funded and therefore sub-standard. The government of Nigeria in a number of documents had stated that teaching and research in universities play a vital role in national development, it therefore follows that funding of universities needs to be given meaningful attention.

Considering the importance of university education, Ajayi and Ekundayo (2007) submitted that funds allocated to higher (university) education should not merely be considered as an expense, but a long-term investment which is of benefit to society as a whole. This is true in view of the fact that graduates of universities impact positively on the political, economic, social and technological development of a nation.

Reviewing the achievements over the years with regard to the contribution of university education, it is obvious that the Federal government have and do recognize the importance of university education. Without university education, the country cannot meet its various development target especially the MDGs and Vision 2020.

The concern for quality university education in Nigeria comes to the fore in realization of the potential impact of the products of the university on national development. Quality university education enables individuals to grow intellectually and also use the skills acquired to contribute meaningfully to the development of the society. Quality university education in the view of Tawari (2002) is a function of funding. Higher Educational Institutions HEIs 
(universities) are, in the main, relied upon to provide the broad array of quality education and training for the development of the individual for flexibility, adaptability and continuous learning (Olufemi, 2012). Quality university education is the livewire for national development. It is therefore surprising that underfunding of university education has become a recurring decimal. Therefore if Nigeria is ready in its quest to become one of the largest economies in the world by the year 2020, then it must see the urgent need to invest adequately in the educational system and particularly in the university system.

\section{Brief History of University Education in Nigeria}

The history of university education as stated by Wikipedia (2014) dates back to the Elliot commission of 1943, which moved the establishment of University College Ibadan (now University of Ibadan) in 1948. The recommendation of the Ashby Commission in 1959 set up by The British Colonial Government to study the need for university education in Nigeria led to the establishment of University of Nigeria, Nsukka in 1960 by the Eastern Region, University of Ife (now Obafemi Awolowo University) in 1962 by the Western Region, Ahmadu Bello University, Zaria in 1962 by the Northern Region and the University of Lagos (1962) by the Federal Government. Furthermore, it continued by saying that these universities were fully funded by the Federal government and that the primary objective was to meet the manpower development and set basic standard for university education in Nigeria.

More so, it noted that the increasing population of qualified students for university education and growing needs for scientific and technological development prompted the establishment of 12 additional universities between 1970 and 1985. However, the need to address technological and agricultural demands also prompted the setting up of 10 additional universities between 1986 and 1999. Consequently, there arose the need to meet the increase in demand for education and address the problem of globalization and this gave birth to 8 additional universities between 1999 and 2012. As at today (2014) the Nigerian University system is composed of 129 Universities (40 Federal, 39 State and 50 Private) with the following features:

Student Enrolment (Undergraduate)

Student Enrolment (Post-Graduate)

Total Student Enrolment

No. of Academic Staff

No. of Senior Non-Teaching Staff

No. of Junior Staff

Total No. of Staff

(Source: Adedipe 2014)
862,601

98,804

961,405

39,780

37,535

44,100

121,415 


\section{Funding of University Education in Nigeria}

Education as an engine of sustainable development depends on its quality. Severally, it has been said that no nation can develop beyond the quality of its educational system.

Presently, the funding of public universities in Nigeria rests upon the shoulders of the Federal Government. University Education is the live-wire of any nation that seeks to achieve its development objectives speedily. During the 1960s and early 1970s when there were fewer universities revenue generated from groundnut, oil palm cocoa and coffee with petroleum was enough for both capital and recurrent projects of universities in Nigeria, the funding situation in the University system was considered adequate until the late 1970s and early 1980s when the situation began to change, a situation in the university that was said to be causing considerable tension and stress within the university system during the periods (Onoh, 1982), Similarly, Babalola (2002) and Samuel (2003) further affirm that Federal Universities in Nigeria are lacking the financial resource to maintain educational quality in the face of enrolment explosion and this has led to brain-drain of the academics. Additionally, the dwindling resources of the Federal Government as a result of other sectors competing for same resources have continuously threatened the funding of university education. Presently, the singular damning problem of Nigerian Universities is the tussle between the Federal Government of Nigeria and the Academic Staff Union of Universities (ASUU), and the bone of contention has been underfunding. Ajayi \& Ekundayo's (2007) belief that the problem that bedevils Nigeria's tertiary education most has been that of underfunding lands credence to this. However, the Federal Government in October 2009 signed an agreement with ASUU to revitalize the universities and the agreement basically centres on funding and the allocation of 26 percent of the annual budget to education but the Federal Government has not shown enough political will to implement the agreement, which has led to ASUU strike almost every year. This problem constitutes a national embarrassment that has placed doubt in the quality of university education in Nigeria.

Funding of university education has remained one of the most challenging problems of the universities and the Federal Government. In a bid to reverse this, the President Yar'Adua's administration elaborated a "7-Point Agenda" in order to achieve sustainable development. The 7-point agenda sees education as the bedrock of development, but the Yar'Adua administration could not fulfil its promises on education because of his demise. President Goodluck Jonathan launched a transformation agenda when he assumed office. The agenda is based on a summary of how the Federal Government intends to deliver projects, programmes and key priority policies from 2011-2015. Despite the transformation agenda, the state of university education is pathetic and quality is on the decline but the pertinent question begging for answer at this juncture is: Has there been any serious improvement on the funding of university education after the agreement? No doubt, Nigerian government over the years and presently has not been meeting the United Nations Educational Scientific and Cultural Organization (UNESCO) recommendation of $26 \%$ of the total annual budget allocation to the education sector. It is even more worrisome to note that the problem of inadequate funding is at a chronic condition now and needs an urgent attention if quality education is to be achieved. The implementation of the report of the Needs assessment of the 
Nigerian universities is a bold step in the right direction in order to salvage the declining quality of university education in Nigeria.

The Federal Government budget allocation to University education in the years past is examined in the section that follows:

Table 1: Federal Government budgetary allocation to Federal Universities in Nigeria (Some selected years)

\begin{tabular}{|l|l|l|}
\hline Year & $\begin{array}{l}\text { Total F.G. } \\
\text { Expenditure (Nm) }\end{array}$ & $\begin{array}{l}\text { Fed. Allocation to } \\
\text { Federal Universities } \\
\text { (Nm) }\end{array}$ \\
\hline 1991 & $1,554.20$ & $1,194.60$ \\
\hline 1992 & $2,060.40$ & $1,410.60$ \\
\hline 1993 & $7,999.10$ & $5,753.00$ \\
\hline 1994 & $10,283.83$ & $9,650.00$ \\
\hline 1995 & $12,728.70$ & $1,480.40$ \\
\hline 1996 & $15,351.80$ & $3,292.90$ \\
\hline 1997 & $15,946.00$ & $6,260.70$ \\
\hline 1998 & $27,721.30$ & $4,214.40$ \\
\hline 1999 & $31,568.10$ & $29,902.80$ \\
\hline 2000 & $67,536.12$ & $33,843.40$ \\
\hline 2001 & $59,744.20$ & $78,066.80$ \\
\hline 2002 & $109,455.20$ & $32,694.30$ \\
\hline 2006 & $151,723.50$ & \\
\hline
\end{tabular}

Source: Okebukola (2003) and Federal Government Annual Budget (2006).

Table 1 shows the Federal Government's allocation to Federal universities. It indicates that there is a fluctuation in the funding of universities in the country. 


\section{Ml Macrothink}

International Journal of Human Resource Studies

ISSN 2162-3058

2015, Vol. 5, No. 2

Writing on trends in funding Federal universities in Nigeria, Ibiam and Okunnamiri (2007) said that major turning points are discernible in the funding of universities in Nigeria. Quoting Nwidiani (2000) they stated that between 1948 and the beginning of the oil boom period, the universities secured funds largely from government grants and tuition fees. However, they noted that a turning point occurred when the economy was literally awash with funds as a consequence of the oil boom, so that by the early 70s when the boom was starting to pick up, the fee structure became skewed in favour of government subvention and at the same time, tuition fee was annulled and user fees reduced. They continued by saying that by 1973, tuition was made free and hostel accommodation set at N90. When the oil boom was over, government grant was cut and the upward adjustment of the user fees and introduction of tuition fees to cushion the cut in subvention could not be achieved because of stiff opposition from student body at that time. From then on the revenue accruing to the university gradually commenced a steady decline. They also noted that the Structural Adjustment Programme (SAP) of the mid-80s to early 90s took a toll on the funds available to the university coupled with the unfavourable exchange regime of the Naira and the attendant high inflation further depressed the purchasing power of the universities. Supporting, Aghanta (cited in Ibiam and Okunnamiri 2007) noted that the revenue of the universities could hardly support the purchase of equipment and library resources from overseas suppliers. Decay then set in and the system began to deteriorate. By 1999 a major change in the funding pattern emerged as the Obasanjo administration was committed to reversing the decay through the injection of more funds into the university system. However, from 2007 - 2014, the Federal Government applied the "envelop system". In this system, the allocation of funds has nothing to do with the university budget. Government gives a maximum amount for everything, items are specified according to budget heads. This means that a university cannot spend more than accordingly given. Currently, the 2014 budget allocation to the education sector translates to 10.6\% only (Budget Office, 2014). The increase in the allocation for education is commendable when compared to 2013 allocation which was 9percent, although this still is inadequate considering the level of deterioration in public education. 
Table 2: Total Government Grant and Local Income in Federal Universities 2003

\begin{tabular}{|l|l|l|l|l|}
\hline Institution & TR $(\mathbf{R C})(\mathbf{N})$ & $\mathbf{L I}(\mathbf{N})$ & $\mathbf{T I}(\mathbf{N})$ & COL2 \% (3) \\
\hline Ibadan & $2,509,890,696$ & $196,575,448$ & $2,706,466,144$ & 7.8 \\
\hline Lagos & $1,955,127,150$ & $359,502,258$ & $2,314,629,408$ & 18.4 \\
\hline Nsukka & $2,512,793,291$ & $98,141,298$ & $2,810,834,589$ & 3.9 \\
\hline Zaria & $2,567,587,409$ & $73,210,330$ & $2,640,797,739$ & 2.9 \\
\hline Ife & $2,304,114,896$ & $40,031,187$ & $2,344,148,083$ & 1.7 \\
\hline Benin & $1,949,126,834$ & $155,172,513$ & $2,104,299,347$ & 8.0 \\
\hline Jos & $1,332,790,023$ & $48,744,424$ & $1,381,534,447$ & 3.7 \\
\hline Calabar & $1,227,113,256$ & $105,939,905$ & $1,333,053,161$ & 8.8 \\
\hline Kano & $981,801,323$ & $54,218,393$ & $1,036,019,716$ & 5.5 \\
\hline Maiduguri & $1,089,098,496$ & $137,148,440$ & $1,226,248,938$ & 12.6 \\
\hline Sokoto & $651,927,799$ & $39,025,328$ & $690,953,127$ & 6.0 \\
\hline Ilorin & $1,472,655,002$ & $65,616,425$ & $1,548,571,427$ & 4.5 \\
\hline Port- Harcourt & $1,268,403,040$ & $110,415,425$ & $1,378,818,465$ & 8.7 \\
\hline Abuja & $402,154,078$ & $84,674,826$ & $486,828,906$ & 21.1 \\
\hline Awka & $1,013,481,643$ & $86,476,190$ & $1,009,954,83$ & 8.5 \\
\hline Uyo & $801,835,95$ & $34,697,558$ & $836,555,468$ & 4.4 \\
\hline Owerri & $611,326,365$ & $29,751,258$ & $641,077,623$ & 4.9 \\
\hline Akure & $545,315,202$ & $35,855,281$ & $581,170,483$ & 6.6 \\
\hline Minna & $417,130,171$ & $20,549,000$ & $437,676,171$ & 4.9 \\
\hline Bauchi & $556,280,147$ & $17,268,097$ & $537,548,244$ & 3.1 \\
\hline Yola & $499,590,326$ & $21,962,043$ & $521,552,369$ & 4.4 \\
\hline TOTAL & $\mathbf{2 6 , 6 6 9 , 5 4 4 , 0 6 0}$ & $\mathbf{1 , 8 1 5 , 1 7 6 , 6 2 7}$ & $\mathbf{2 8 , 4 8 4 , 7 2 0 , 6 8 7}$ & $\mathbf{6 . 8}$ \\
\hline & & & & \\
\hline
\end{tabular}

Source: NUC, 2003 (Report on performance of the Federal University System.)

\section{Ubogu, 2011 (Financing Higher Education in Nigeria)}

Table 2 shows that funding in the Nigerian university system is derisory. This according to Ubogu (2011: 14) led to the stakeholders National Summit on Higher Education in the year 2003 where a number of conclusions were reached on the issue of funding of higher education, thus:

1. An increase in the funding levels to universities is required to enable them improve on the provision of facilities and services. Universities must increase their internally generated 
funding levels.

2. All stakeholders should be challenged to share in the funding of education by paying some fees in order to attain and sustain a reasonable level of funding for higher education in Nigeria.

3. Government should implement and sustain the provision of scholarship, business and loans to ensure that all Nigerians with capacities to seek education at the tertiary level can actualize them.

4. Development partners have great potentials to bring in significant resources to the institutions and agreed that these potentials be comprehensively explained with due cognizance to national interest.

\section{Underfunding and Qualitative University Education in Nigeria}

Quality is a word that is often used by many people in almost all walks of life and it means different things to different people. However, the fact remains that quality has become an indispensable part of organizations, government, industry, businesses, as well as in education.

In education especially at the university level, quality is a core value upon which the activities of the university are hinged. It is therefore not surprising that universities are faced with quality issues and the search for solutions to such issues is often taken seriously.

Babalola, Adedeji \& Erwat (2007) noted that quality is a multidimensional concept and should not be taken for granted, but must be defined each time it is used for investigations. Commonly cited definitions of quality include - "fitness to purpose" in relation to the user and customer needs. Quality can also be taken to mean that the "product conforms to standards, specifications or requirements" (Babalola, Adedeji \& Erwat, 2007). Furthermore, they stated that:

Product in industry is definable and tangible item (output), manufactured according to specifications and ready for sale. However, product in education may be referred to 'output', that is 'graduands' who are awarded certificates having fulfilled all stipulated requirements. They are attested to possess knowledge and skills with which they can impact society (p.242).

Similarly, Longe (1999) asserted that the quality of education includes the learning environment (process) and the students' outcomes (graduands). Noting that the graduands should be able to go out to the society and prove their worth by their level of performance in the competitive labour market. The assertion above implies that for a country to 'beat its chest' as having qualitative university education, graduates from its universities must be comparable and competitive in terms of knowledge and skills to other international graduates.

\section{What is the current situation in Nigeria?}

Writing on the quality of education in Nigeria, (Longe; Letuka; and Adedeji et al cited in Babalola, Adedeji \& Erwat 2007) affirmed that quality of education especially in tertiary 
institutions needs to be urgently addressed. Several reasons have been adduced to explain the low quality of university education in Nigeria. Poor schooling is cited by Babalola, Adedeji \& Erwat as the greatest barrier to political, social and economic transformation in Nigeria today. Corroborating Babalola et al (2007), Adedeji et al (2003) submit that poor quality schooling is exhibited in many ways such as an increased rate of absenteeism and ineffective teachers in schools and the quality of children (graduands) to read and write effectively. A clear evidence of the low quality of graduates from Nigerian universities is revealed by employers who complain that they (graduates) are not employable because they lack the requisite skills that are needed in today's workplace.

Generally speaking, graduates from Nigerian Universities are thought to be of lower quality when compared to graduates of other universities across the globe, even those who graduate from universities in other African countries are thought to be superior. This explains the rush by Nigerians to universities outside the country.

Longe (1999) noted that quality of education includes the learning environment and students' outcome. They assert that there are two broad approaches to measuring quality: The first involves measuring the 'outputs' from the educational system and the second has to do with examining the 'educational processes' which produce these outputs. These approaches can be used separately or together (Babalola et al). Furthermore, they stated that from the input side quality of education can be measured through students' capacity and motivation to learn and the curriculum or the subjects to be learned. They also mentioned other ways of inferring quality from the input side as follows:

- teachers who know how to teach and can actually teach

- time for learning and

- requisite tools for teaching and learning

The output indicators for measuring quality education they noted include: the qualification and the levels of competence in the performance of the outputs (graduates) using the knowledge and skills acquired. Other indicators are: performance of the outputs in the job competitive market, their impact on moral conduct, and serviceability in the society.

Many stakeholders - practitioners, customers and critics are of the view that given the criteria for measuring quality of education as enunciated above, the pendulum of measuring quality education swings to the low side. The major factor that is often mentioned is the issue of underfunding. Underfunding of universities in Nigeria has affected universities negatively in a number of ways:

- Inadequate infrastructural development

The production of goods and services in any organization is usually dependent on the availability of production resources. The paradox accompanying this is that despite the investment in education, the Nigerian universities are fast decaying. The necessary resources needed for effective teaching and learning to foster economic development are in short supply. Lecturers and students have been greeted with inadequacies in the area of accommodation, 
reduction in space per student, overcrowded classrooms, obsolete library materials, poorly equipped workshops and laboratories for practical, inadequate office space, insufficient instructional materials etc. Underfunding limits the provision of Information and Communication Technology (ICT). One of the recent developments in the world which is contributing positively to education delivery around the world is the introduction of ICT. ICT has become a veritable tool for the improvement of university education around the world but in Nigerian universities, provision of ICT is low. Decrying the low level of funding of higher education, Akubuilo (2007) said "the current level of funding of education in Nigeria with decreasing budgetary allocation is a major area of constraint in the provision of effective computer education to science students". Provision of ICT is therefore very fundamental in assisting the educational sector achieve its goals. Inadequate provision and sometimes outright lack of ICT caused by underfunding is a serious problem impinging on quality of Nigerian Universities.

\section{- Brain-drain syndrome}

This is the movement of academic staff from Nigerian universities to the industries and to overseas countries where their services are better rewarded. Bangura (1994), observed that between 1988 and 1990 over 1000 lecturers left the federal university system in Nigeria. Similarly, Odekunle in Ajayi \& Ekundayo (2007) lamented that the universities lost lecturers in sensitive and critical areas of development in tertiary institutions both within and outside the continent. The salary of a university professor is no way near that of a councillor in a local government area because of underfunding. Many professors are therefore engaged in "moonlighting" activities in order to make ends meet and this has affected the quality of teaching and service delivery in universities and in some cases capital flight. It is worthy of note that while the best brains are leaving the university system, the aim of producing high level manpower required for sustainable development cannot be fully achieved.

- Incessant strike

The financial imbroglio in the nation's ivory tower and the subsequent federal government's refusal to accord the university its pride of place in terms of allocation of adequate funds has over the years been generating a very unpalatable discord between the ASUU and the Federal Government (Ajayi \& Ekundayo 2007). However, the Federal Government and ASUU had entered into an agreement but the failure on the part of the Federal Government to implement this agreement has resulted to several strikes in the university system. The weakness of the university system over a long period of time is as a result of underfunding. The strike actions have kept universities in Nigeria behind the academic calendar and students' time has been wasted. For instance, the 2013 strike which lasted for about six (6) months affected the students' academic year such that the number of contacts students had with their lecturers was drastically reduced and consequently a lot of grounds was lost. Students therefore do not master the subject matter as they are rushed through the scheme of work. This has affected the quality of graduates produced in the Nigerian University system negatively. On the other hand, work pressure on the university lecturers continue to mount as they are expected to cover the course work within short period of time. All this happened because the Federal 
Government had failed to allocate adequate funds to university education. If the problem is not properly addressed, it will cripple the entire economic system. The key to quality university education lies in the hands of the Federal Government and Academic Staff Union of Universities (ASUU). The issue of underfunding which has remained a vexed issue between ASUU and the Federal Government need to be resolved if quality university education must be achieved.

- Low research output

The underfunding of university education in Nigeria affects university research. According to World Bank (1994) the equipment for teaching, research and learning are either lacking or very inadequate and in bad shape to permit universities the freedom to carry out the basic functions of academics. The writing by Zayyard in Akindutire (2004:37) that:

"It has been difficult to attract enough good people into the university system not only because the general conditions of service are not sufficiently attractive but also because facilities for meaningful research are not just there."

Seem to the fact that underfunding has dealt a very big blow to quality education in Nigeria. Consequently, the university lecturers who are involved in the transmission of knowledge to the learners cannot even undergo an approved professional training; undertake national and international research, seminars, conferences, workshop training and field trip which are supposed to develop their intellectual capacity. Also, underfunding limits the development of research ideas as some institutions do not have the fund to even develop their research results. Confirming this state of affairs, Ugorji (1995) cited in Anuna \& Ukpabi (2007) found that funding of Nigerian universities has been posing critical problems and constraints to top university administrators. Furthermore, she noted that there was a consensus among vice chancellors that gross underfunding was one of the major stressors in both Federal and State universities.

- Quality of Graduates

Nigerian universities today are producing quantity instead of quality graduates due to inadequate library and laboratory facilities, infrastructure and over-enrolment. Supporting this point of view, Okwori \& Okwori (2007: 96) noted:

Many universities are without good libraries. What one finds in the libraries are outdated books and current journals and researches in relevant disciplines are not available. Laboratories are without chemicals, workshop tools and equipment have broken down and the latest ones are not available. These are just some of the woes in universities today.

The poor development can be traced to budgetary allocation to university education as the materials needed for quality delivery cannot be purchased with inadequate funds. University education as the livewire of national development requires adequate funding.

Inadequate provision of facilities is a serious aspect that affects graduates of universities. The quality of graduates depends on the available materials at the disposal of universities. It is however surprising that the Federal Government has ignored the provision of the necessary 
equipment required to produce quality graduates. Currently, many graduates of Nigerian universities find it very difficult to face modern challenges in the world of work due to the fact that they lack the requisite skills they should have acquired while in the university if adequate financial and material resources were provided.

\section{Conclusion}

The paper has shown that the issue of underfunding of university education in Nigeria is a recurring one and cannot be glossed over. It has also shown several ways that underfunding has impinged on quality education in universities. The political class have not committed adequate fund to university education. This has been responsible for the declining quality of university education. The Federal Government allocation to universities is nowhere close to the $26 \%$ of total budget recommended by UNESCO. For the university system in Nigeria to achieve its goals effectively and contribute to the much desired economic and technological transformation speedily, there is need for adequate funding.

\section{Recommendations}

In order to make more money available for universities,

1. The government should muster enough political will and allocate at least $26 \%$ of the total budget to university education as prescribed by UNESCO.

2. Use of the fund allocated to the universities should be closely monitored to forestall misappropriation and misapplication of fund.

3. Allowances paid to political office holders should be reviewed downwards and money accruing from such exercise should be channelled towards providing state-of-the-art laboratories and libraries in universities.

4. Religious organizations as a matter of fact absorb many products (graduates) of universities. They should be made to contribute to university funding by paying a stipulated percentage of their monthly/yearly income to government to augment university fund.

5. Multinational companies as part of their corporate social responsibilities should be made to pay a substantial amount of their monthly/yearly income to universities in their areas of operation.

6. Internally generated revenue (IGR) should be prudently spent as this will make more money available in the hands of administrators to execute university activities.

7. Financial account of universities should be audited regularly so that anomalies would be rectified easily before it gets out of hand. This will also cause university administrators to be accountable. 


\section{Macrothink \\ International Journal of Human Resource Studies \\ ISSN 2162-3058 \\ 2015, Vol. 5, No. 2}

\section{References}

Adedipe, N.O. (2014). Strains and Stresses in the Nigerian University System: Sustainable Quality Assurance Prospects by Private Universities. Being Text of the Third Convocation Lecture of the Al-Hikmah University, Ilorin.

Ajayi, J.A. \& Ekundayo, H.T. (2007). Funding Initiatives in University Education in Nigeria in J.B. Babalola, G.O. Akpan, A.O. Ayeni \& S.O. Adedeji (Eds.) Access, Equity and Quality in Higher Education. NAEP Publication: 562-568.

Akindutire, I.O. (2004). Administration of Higher Education. Lagos Sunray Press.

Akubuilo, D.U. (2007). Effective Utilization of Information Communications Technology (ICT) in Science instruction at Tertiary Level: Some Inhibiting Factors, in J.B.

Babalola, G.O.Akpan, A.O. Ayeni \& S.O. Adedeji. (Eds.) Access, Equity and Quality in Higher Education. Pg. 513-519.

Anuma, M.C. \& Ukpabi, H.D. (2007). Funding Initiatives: The Case of the Universities, in J.B. Babalola, G.O. Akpan, A.O. Ayeni \& S.O. Adedeji (Eds.). Access, Equity and Quality in Higher Education: 555-562.

Babalola, J.B., Adedeji, S.O. \& Erwat, E.A. (2007) Revitalizing Quality Higher Education in Nigeria: Options and Strategies, in J.B. Babalola, G.O. Akpan, A.O. Ayeni \& S.O.

Adedeji (Eds.) Access, Equity and Quality in Higher Education. NAEP Publication: 241-262.

Babalola, J.K. (2002). Education and National Ethics. A Keynote Address Delivered at Workshop on use of Global Knowledge in University Management, University of Ibadan.

Bangura, Y. (1994). Intellectuals, Economic Reform and Social Change: Constraints and Opportunities in the Formation of a Nigerian Technology. Development and Change, 25(2): 261- 305.

Federal Government Budget (2006).

Ibiam N. \& Okunnamiri, P.O. (2007). Funding University Education in Nigeria, in J.B.

Babalola, G.O. Akpan, A.o. Ayeni \& S.O. Adedeji (Eds.) Access, Equity and Quality in Higher Education.

Ibukun, W.O. (1997). Educational Management - Theory and Practice, Ado-Ekiti, Green-Line Publishers.

Longe, R.S. (1999). Investment in Nigeria Education: Relevance, Quality and Governance at the Eve of the Third Millennium. An Inaugural Lecture, University of Ibadan.

National Universities Commission (NUC, 2003). Report on the performance of the Federal University System. 


\section{Macrothink}

International Journal of Human Resource Studies

ISSN 2162-3058 2015, Vol. 5, No. 2

Okebukola, P. (2003). Issue in Funding University Education in Nigeria. NUC Monograph Series. Abuja: National Universities Commission.

Okwori, A. \& Okwori, A.G. (2007). Federal Character and Geographical Spread of Universities: Implications for Quality and Access to University Education in Nigeria.

In J.B. Babalola, G.O.Akpan, A.O. Ayeni \& S.O. Adedeji. (Eds.) Access, Equity and Quality in Higher Education: 615 - 630 .

Olufemi, A.B. (2012). Sustainable Financing of Higher Education in Nigeria - Funding Models. A paper presented at the Politics Dialogue. Trust Africa Learner.

Onoh, J.K. (1982). Summary of a Seminar Paper on Profit Making Center in University Management, CEREMAC. University of Ibadan.

Samuel, T. (2003). Strategies for Raising Additional Resources for Education. EducationToday, 10(1): 40-43.

Tawari, O.C. (2002). Developing a Total Quality Management System For Tertiary Education in Nigeria (Inaugural Lecture Series 10), Port-Harcourt: Rivers State University of Science and Technology, Nigeria.

Ubogu, R.E. (2011). Financing Higher Education in Nigeria. Journal of Research in Education

Wikipedia (2014). http://www.universitiesofNigeria.org

2014 Budget Allocation to Education Sector, http://www.budgetoffice.gov.ng, retrieved in October, 2014. 